\title{
Medical Image of the Week: Chylothorax
}
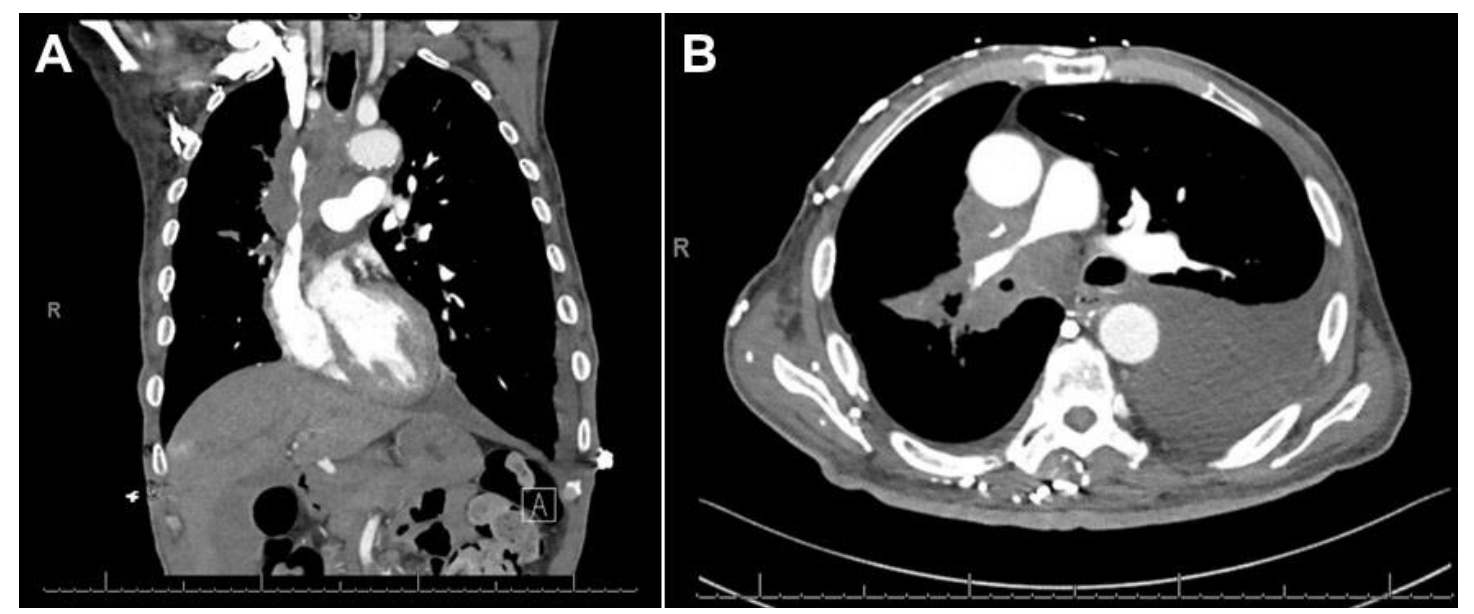

Figure 1. A: CT of the chest (coronal image) demonstrating large right hilar and mediastinal adenopathy, leading to moderate to severe narrowing of the superior vena cava (SVC). B: CT of the chest (axial image) demonstrating moderate to severe narrowing of the pulmonary artery trunk due to compression from mediastinal adenopathy. A left pleural effusion is noted.
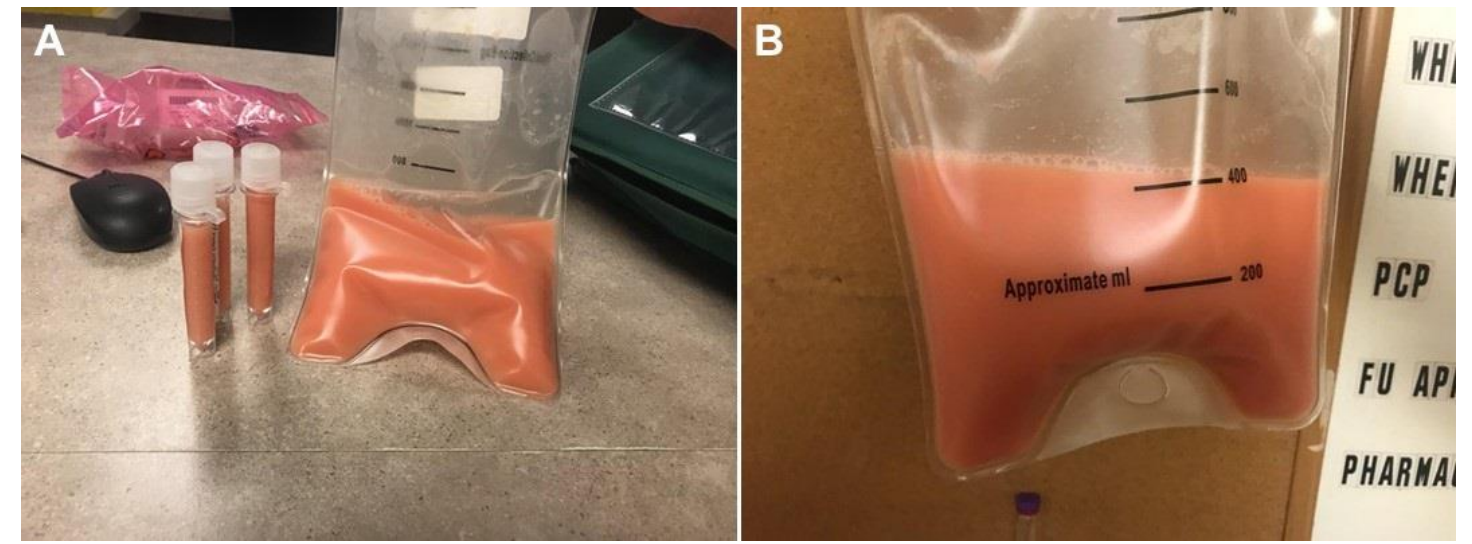

Figure 2. Pleural fluid sample demonstrating milky, pink fluid. The triglyceride level was $532 \mathrm{mg} / \mathrm{dl}$ and cholesterol level $63 \mathrm{mg} / \mathrm{dl}$.

A 73-year-old man with untreated stage IV adenocarcinoma of the lung was admitted to the hospital with several days of progressively worsening dyspnea on exertion. The chest CT showed a large left pleural effusion with enlarging bilateral hilar and mediastinal lymphadenopathy, compression of the superior vena cava and right main pulmonary artery consistent with progressive lung cancer (Figure 1). Therapeutic and diagnostic left sided thoracentesis was performed, removing approximately $450 \mathrm{ml}$ of milky, pink fluid suggestive of hemochylothorax (Figure 2). Analysis of the fluid was significant for 27,720 red blood cells, 476 total nucleated cells with lymphocyte 
predominance (87\%), glucose $158 \mathrm{mg} / \mathrm{dl}$, cholesterol $63 \mathrm{mg} / \mathrm{dl}$, and amylase $28 \mathrm{U} / \mathrm{L}$. The pleural fluid was exudative (protein $4.4 \mathrm{~g} / \mathrm{dl}$ ) with a significantly elevated triglyceride level of $532 \mathrm{mg} / \mathrm{dl}$. No malignant cells were identified in the fluid.

This case illustrates a nontraumatic chylothorax secondary to metastatic adenocarcinoma of the lung. The leading cause of non-traumatic chylothorax is malignancy by compression and/or lymphangitic invasion (1). Thoracic duct invasion or leak can only be seen with nuclear medicine scintigraphy; however, this test was not performed on this patient. The appearance of the pleural fluid in chylothorax can be deceiving as less than half of pleural fluid samples will be milky in appearance (2). In addition, milky appearing pleural fluid is not specific for a chylothorax, as milky fluid can be seen in a cholesterol pleural effusion (pseudochylothorax) or an empyema. The detection of chylomicrons on pleural fluid lipoprotein electrophoresis is the definitive diagnostic criterion for chylothorax, however it is not widely available and is costly (3). The classic diagnostic criterion is a pleural fluid triglyceride level of $>110 \mathrm{mg} / \mathrm{dl}$ in an appropriate clinical setting of mediastinal malignancy, lymphoma, recent thoracic surgery or penetrating trauma to the neck or thorax (4). A pleural fluid triglyceride level between 50 and $110 \mathrm{mg} / \mathrm{dl}$ does not exclude the diagnosis of chylothorax and clinicians should perform lipoprotein electrophoresis of the pleural fluid to detect chylomicrons. To distinguish a chylothorax from a pseudochylothorax (both have milky appearance), clinicians should obtain a cholesterol level on the fluid. The cholesterol level in a chylothorax is usually less than $200 \mathrm{mg} / \mathrm{dl}$ while a pseudochylothorax will have high levels, typically greater than $200 \mathrm{mg} / \mathrm{dl}$.

The patient chose to undergo palliative radiation of the chest and symptomatic treatment of his dyspnea.

John Dicken $M D^{1}$, Madhav Chopra $\mathrm{MD}^{2}$, Faraz Jaffer $\mathrm{MD}^{2}$ and Linda Snyder MD² ${ }^{1}$ Department of Internal Medicine and ${ }^{2}$ Division of Pulmonary, Allergy, Critical Care and Sleep

Banner University Medical Center-Tucson

Tucson, AZ USA

\section{References}

1. McGrath EE, Blades Z, Anderson PB. Chylothorax: aetiology, diagnosis and therapeutic options. Respir Med. 2010 Jan;104(1):1-8. [CrossRef] [PubMed]

2. Maldonado F, Hawkins FJ, Daniels CE, Doerr CH, Decker PA, Ryu JH. Pleural fluid characteristics of chylothorax. Mayo Clin Proc. 2009 Feb;84(2):129-33. [CrossRef] [PubMed]

3. Hooper C, Lee YC, Maskell N; BTS Pleural Guideline Group. Investigation of a unilateral pleural effusion in adults: British Thoracic Society Pleural Disease Guideline 2010. Thorax. 2010 Aug;65 Suppl 2:ii4-17. [CrossRef] [PubMed]

4. Staats BA, Ellefson RD, Budahn LL, Dines DE, Prakash UB, Offord K. The lipoprotein profile of chylous and nonchylous pleural effusions. Mayo Clin Proc. 1980 Nov;55(11):700-4. [PubMed] 